\title{
Factor Structure of Slovak Adaptation of Attentional Control Scale
}

\author{
Drahomír Michalko \\ Faculty of Social and Economical Sciences, Comenius University
}

\begin{abstract}
The Attentional Control Scale (ACS) is a tool developed to assess the ability to voluntarily control attentional resources. The current aim was to verify the factor structure of the scale and its hypothesized inverse relationship with measures of trait anxiety on Slovak sample. The Principal Component Analysis (PCA) suggested two correlated factors resembling the hypothesized Focusing and Shifting subscales. The factorial solution suggested by the PCA had the best fit against one-factorial and two-factorial orthogonal solutions in the Confirmatory Factor Analysis (CFA) conducted on an independent sample. The entire scale had good internal consistency $\left(\omega_{t}=.85\right)$. The Focusing $\left(\omega_{t}=.81, \alpha_{\text {ord }}=.81\right)$ and Shifting $\left(\omega_{t}=.67, \alpha_{\text {ord }}=.66\right)$ subscales reached acceptable to good values of internal consistency. The ACS showed a negative relationship with trait anxiety inventory and behavioral inhibition scale. The differences of our results compared to other studies investigating factor structure of ACS are discussed, together with limitations of the current study, validity and applicability of the scale.
\end{abstract}

Key words: Attentional Control Scale, factor structure, internal consistency, trait anxiety, selfreport measures

Attentional control can be conceptualized as a unitary construct, however two dichotomous components have been proposed (Derryberry \& Reed, 2002; Taylor, Cross, \& Amir, 2016; Telzer et al., 2008). Focusing denotes the ability to withhold attentional focus on a relevant target while ignoring distracting, although significant stimuli. Shifting is related to the concept of cognitive flexibility and, as such, represents the ability to voluntarily disengage attention from a target that is no longer relevant to the task at hand and shift it to another target. The Attentional Control Scale (ACS) is a self-report tool designed to assess individual differences in the ability to voluntarily control attentional resources (Derryberry \& Reed, 2002).

Correspondence concerning this article should be addressed to Drahomír Michalko, Institute of Applied Psychology, Faculty of Social and Economical Sciences, Comenius University, Mlynské Luhy 4, Bratislava, 82105, Slovak Republic. E-mail: drahomir.michalko@uniba.sk

Received January 15, 2018
Regarding the psychometric properties of ACS, its first version consisted of two separate scales, namely Focusing and Shifting subscales (Derryberry \& Rothbart, 1988). These two scales were later compiled into one scale (ACS), which, according to the authors (Derryberry \& Reed, 2002), was supposed to reflect the correlated factors of attentional focus, attentional shift, and flexible control of thought. However, studies examining psychometric properties of ACS are still quite recent. Considering the factor structure of the scale, Verstraeten, Vasey, Claes, and Bijttebier (2010) conducted a Confirmatory Factor Analysis (CFA) of the Dutch version of ACS on a sample of children from 8 to 18 years old. They reported the two-factor solution (with positively correlated factors) having a superior fit to the one-factor solution. Reliability estimates (Cronbach's alpha $-\alpha$ ) for the Focusing and Shifting subscales reported in this study were $\alpha=.70$ and $\alpha=.63$, respectively. The Icelandic version of ACS (Ólafsson et al., 2011) also yielded two components, when submitted to 
the Principal Components Analysis (PCA). This two-factor model with strongly correlated factors was reasonably supported by CFA on an independent sample. Internal consistency of the subscales was comparable to the values reported in Verstraeten, Vasey, Claes, and Bijttebier (2010). The fact that Ólafsson et al. (2011) also hypothesized and tested differential dependency of ACS subscales with symptoms of anxiety and depression is noteworthy. They found the Focusing subscale to be uniquely associated with trait-anxiety, while the Shifting subscale was uniquely associated with symptoms of depression. In a study conducted by Judah, Grant, Mills, and Lechner (2014), the English version of ACS has also been found to be composed of two related factors in PCA as well as in CFA. Again, internal consistency of the subscales was $\alpha=.82$ for Focusing and $\alpha=.71$ for Shifting subscale. Recently, Abasi, Mohammadkhani, Pourshahbaz, and Dolatshahi (2017) reported two factors from an exploratory factor analysis conducted on an Iranian sample with internal consistency and test-retest reliability after two weeks for the Focusing subscale $(\alpha=.78, r=$ $.80)$ and for the Shifting subscale $(\alpha=.66, r=$ $.72)$. It is worth to mention that these studies used the $\alpha$ coefficient to estimate internal consistency of the whole scale as well as of its subscales, despite the evidence from either PCAs or CFAs, suggesting a clear violation of the tau-equivalency and uni-dimensionality assumptions (Graham, 2006). Finally, the reported studies differed in final number of retained items in ACS, mainly due to insufficient factor loadings of certain items.

The concept of attentional control stems from the Attentional Control theory (Posner \& Petersen, 1990), which was developed in order to account for the effects of anxiety-related bias of attention towards a threat (Bar-Haim, Lamy, Pergamin, Bakermans-Kranenburg, \& van IJzendoorn, 2007; Derryberry \& Reed,
2002; Taylor, Cross, \& Amir, 2016). Specifically, according to this theory, anxiety disrupts the balance between posterior and anterior systems, heightening the influence of the stimulus driven posterior system and lowering the influence of the goal-directed anterior system (Eysenck, 2007; see also Hermans, Henckens, Joëls, \& Fernández, 2014). Fox, Russo, and Georgiou (2005) suggested that anxiety facilitates automatic processing of threat-related stimuli and hinders the influence of goal-directed processes over attention, with these effects being pronounced in anxiety-inducing environments.

Moreover, it has been reported that high-anxious individuals are more prone to exhibit this attentional bias (Bar-Haim, Lamy, Pergamin, Bakermans-Kranenburg, \& van IJzendoorn, 2007; Derryberry \& Reed, 2002; Koster, Crombez, Verschuere, Van Damme, \& Wiersema, 2006). It has also been assumed that hyper-responsivity of amygdala, as a pre-attentive threat detection system, toward a threatening stimulus in high trait anxiety individuals is responsible for this difference between anxious and non-anxious populations (Mathews, Mackintosh, \& Fulcher, 1997). However, this view has been modified by incorporating the role of prefrontal cortical mechanisms (Öhman, 2005). There have even been reports (Bishop, 2009; Eden et al., 2015; Kim \& Whalen, 2009) suggesting that high trait anxiety might be generally associated with impoverished control mechanisms, regardless of whether they are applied during or in absence of threat-related stimuli exposure.

Indeed, studies examining the relationship between self-report measures of attentional control and trait anxiety have frequently reported their inverse dependency (Abasi, Mohammadkhani, Pourshahbaz, \& Dolatshahi, 2017; Fajkowska \& Derryberry, 2010; Judah, Grant, Mills, \& Lechner, 2014; Ólafsson et al., 2011). However, most of these studies employed the State-Trait Anxiety Inventory (STAI-T) 
(Spielberger, Gorusch, \& Lushene, 1970) as a measure of trait anxiety, which is believed to tap more into the average anxiety level rather than the general sensitivity of anxiety system (Carver \& White, 1994; Fowles, 1987). Despite this, ACS has been found to be negatively associated also with measures of trait-anxiety such as the self-report measure of the behavioral inhibition system (BIS) (Carver \& White, 1994), which do not necessarily reflect only average experience of anxiety on daily basis (Fajkowska \& Derryberry, 2010). Importantly however, we should not view high trait anxiety only as an indicator of a poor attentional control. On the contrary, it has been reported that highly anxious individuals with good attentional control can effectively reduce their bias towards threatening stimuli when given the appropriate amount of time (Derryberry \& Reed, 2002). Considering that highly anxious persons with low attentional control are at increased risk for development of anxiety disorders, some reports suggest that effective interventions by the means of cognitive-behavioral therapy or working memory training may reduce symptoms of anxiety and related attentional bias towards threat (Bowler et al., 2012; Hadwin \& Richards, 2016).

The aim of the current study is to verify the hypothesized two-factor structure of the ACS on a Slovak sample and to provide more suitable reliability estimates of the tool. We anticipated ACS to be formed of two-positively related factors and hence we were expecting twofactorial non-orthogonal solution to have the best fit from amongst one-factorial and two-factorial orthogonal solutions.

Regarding the inverse dependency of attentional control and trait anxiety, we hypothesized the ACS scores to be negatively related to self-report measures of trait anxiety (STAI-T and BIS). Finally, we also hypothesized that only the Focusing subscale is negatively related to measures of trait anxiety.

\begin{abstract}
Methods

\section{Participants}

In total, 474 (354 females) subjects with average age $21.7(S D=2.5)$ years, comprised mostly of university students (majority from Comenius University in Bratislava) of various study programs (e.g., psychology, economics, law, medicine), participated voluntarily in this study. Subjects were not screened for health status or history of mental illness and hence were not selected or removed on this basis. First half of the subjects served for the PCA and the second half for the CFA (see Statistical Analyses).

Prior power analysis suggested that sample sizes for both correlation analyses (see Statistical Analyses) are sufficient for detection of moderate or stronger effects ( $r=.30$ to .50 and more) while $\alpha=.05$ and $1-\beta=.80$.
\end{abstract}

\section{Self-Report Measures}

Attentional Control Scale. Three scales were administered in the form of online questionnaires. Two independent translations of the ACS into the Slovak language (and back to English) were done and final edits were made after mutual consent between two translators. The ACS (Derryberry \& Reed, 2002) includes 20 statements regarding the difficulty to control attention during everyday circumstances (Appendix) to which participant responds on a 4-point Likert scale (almost never-always) with no middle point.

State-Trait Anxiety Scale. The STAI-T subscale for trait anxiety (Spielberger, Gorusch, \& Lushene, 1970) consists of 20 statements with responses organized on a 4-point Likert scale (almost never-almost always), asking subject to report usual frequency of anxiety related physical and mental states. Internal consistency of the scale in our sample reached very good 
values for research purposes $\left(\omega_{t}=.93, \alpha_{\text {ord }}=\right.$ .93).

Behavioral Inhibition Scale. The BIS scale as self-report measure of anxiety system sensitivity (Carver \& White, 1994) is made up of 7 statements also with 4-point Likert response scale (very true for me - very false for me). Internal consistency of the scale in our sample reached adequate level $\left(\omega_{t}=.79, \alpha_{\text {ord }}=.79\right)$.

\section{Statistical Analyses}

Principal Component Analysis. Since the responses on the ACS scale were represented in ordinal form, PCA was conducted on polychoric correlation matrix. Number of components to be extracted was determined by Parallel analysis (Horn, 1965) using 500 randomly generated matrices of equal sample size for comparison. Only components with eigenvalue higher than its 95th percentile counterpart were retained. Assumptions of sampling adequacy and reducibility of the data were tested by Barttlet's test of sphericity and Keiser-MeyerOlkin (KMO) test of sampling adequacy. As we expected components to be correlated, extracted components were rotated by oblique "oblimin" rotation method. Sample size for PCA was $N=$ 237 (166 females) of average age $21.5(S D=2.1)$ years. Parallel analysis and PCA were conducted with psych package in R statistical software (Revelle, 2017).

Confirmatory Factor Analysis. In CFA, the appropriateness of the model was assessed by following fit indices and their optimal values: $\chi^{2} / d f \leq 2$, comparative fit index $(C F I \geq .95)$, Tucker-Lewis index $(T L I \geq .95)$, root mean square error of approximation (RMSEA $\leq .05)$, and standardized root mean square residual $(S R M R \leq .05)$. In addition to the significance of testing the difference between predicted and observed covariance matrices by $\chi^{2}$, we followed the recommendations by Ullman (2006), who suggested the use of the ratio of $\chi^{2}$ to degrees of freedom $\left(\chi^{2} / d f\right)$ in samples larger than 200, since even small discrepancies between the compared matrices might result in a significant difference. We also checked for possible model improvements suggested by modification indices (MI). Since responses on the scale were presented in the form of ordered factors, we used diagonally weighted least squares (WLSVM) (e.g., Flora \& Curran, 2004) as the estimation method, which however did not enable us to compare the tested models directly by means of the AIC or BIC criterion, in the case of non-nested scenario. Therefore, in the comparison between one and two-factorial solutions, we relied only on the quality of fit indices, while in the comparison between the twofactorial orthogonal and non-orthogonal solution, we ran a scaled chi-square difference test (Satorra, 2000). CFA was performed with the lavaan package in $\mathrm{R}$ (Rosseel, 2012) on a sample size of $N=237$ (188 females) with average age of $21.9(S D=2.9)$ years.

Internal consistency. We used four different estimates of internal consistency: ordinal alpha $\left(\alpha_{\text {ord }}\right)($ Gadermann, Guhn, \& Zumbo, 2012), which is more suitable for ordinal data, McDonald's omega total $\left(\omega_{t}\right)$ and hierarchical $\left(\omega_{h}\right)$ (Zinbarg, Revelle, Yovel, \& Li, 2005), and Revelle's beta ( $\beta)$ (Cooksey \& Soutar, 2006; Revelle, 1979), based on the worst split of a test. The coefficients $\omega$ and $\beta$ were utilized for possible violation of tau-equivalency and uni-dimensionality of the scale (Graham, 2006). The polychoric correlation matrix served as an input for all internal consistency estimates. Internal consistency was analyzed using the psych package (Revelle, 2017). The reliability coefficients were estimated on the whole sample.

Correlation analyses. To assess the relationship of ACS and its subscales with measures of trait anxiety, Pearson and Spearman correlation coefficients were chosen based on the prior test of bivariate normality (Henze \& Zirkler, 1990) assumption. We also used partial correlation 
coefficients for testing unique dependencies of the ACS subscales with measures of trait anxiety. The sample for the correlation analysis between ACS and STAI-T consisted of $330 \mathrm{sub}$ jects (242 females) with average age of 21.3 $(S D=1.9)$ years. Relationship between ACS and BIS was estimated on a sample size of $N=130$ (101 females) of average age $22.6(S D=3.5)$ years. Subjects from these samples came from the samples used in PCA and CFA.

\section{Results}

\section{Principal Component Analysis}

Looking at the correlation matrix, we noticed that three items (item 9, 16 and 20) had remarkably poor average inter-item correlation $(<.08)$ with other items compared to the rest of the items (mean polychoric correlation $r_{\text {poly }}=.21$ ) and hence were removed from further analyses. Results of parallel analysis suggested an ex- traction of two components of which eigenvalues surpassed $95^{\text {th }}$ percentile of their randomly generated counterparts.

The data were suitable for reduction $\left(\chi^{2}=\right.$ $429.9, d f=136, p<.001 ; K M O=.787)$. Three items with highest loadings on first component (Table 1) were item 3 ("When I'm working hard on something, I still get distracted by events around me"), item 2 ("When I need to concentrate and solve a problem, I have trouble focusing my attention") and item 7 ("When trying to focus my attention on something, I have difficulty blocking out distracting thoughts"). Eleven items in total loaded ( $>$. 35) on the first component and according to the content of these items, we named this component "Focusing". Two items with highest loadings on the second component (Table 1) were item 19 ("It is easy for me to alternate between two different tasks") and item 10 ("I can quickly switch from one task to another"). Seven items in total loaded $(>.35)$ on the second component and

Table 1 Standardized loadings (pattern matrix) of ACS items after oblique rotation from PCA

\begin{tabular}{llll}
\hline Item & $1^{\text {st }}$ comp. & $2^{\text {nd }}$ comp. & $h^{2}$ \\
\hline 1. Hard to concentrate for me when there are noises around & $\mathbf{. 6 5}$ & .10 & .46 \\
2. Need to concentrate on a difficult task/trouble focusing & $\mathbf{. 7 6}$ & -.01 & .58 \\
3. Working on something/distracted by events around me & $\mathbf{. 8 1}$ & -.19 & .37 \\
4. My concentration is good/music in the room & $\mathbf{. 4 1}$ & $\mathbf{. 3 6}$ & .35 \\
5. When concentrating/unaware of what's going on & $\mathbf{. 5 1}$ & .06 & .27 \\
6. When reading/easily distracted if there are people talking & $\mathbf{. 6 4}$ & .02 & .42 \\
7. Trying to focus/difficult blocking distracting thoughts & $\mathbf{. 7 3}$ & .06 & .55 \\
8. Hard time concentrating/when excited about something & $\mathbf{. 4 5}$ & .07 & .22 \\
10. Quickly switch from one task to another & -.10 & .76 & .56 \\
11. It takes me a while to get really involved in a new task & $\mathbf{. 4 5}$ & .20 & .28 \\
12. Difficult to coord. attention betw. writing and listening & $\mathbf{. 6 7}$ & -.10 & .43 \\
13. Interested in a new topic very quickly when I need to & .19 &. $\mathbf{3 6}$ & .19 \\
14. Easy for me to read while I'm also talking on the phone & .23 & $\mathbf{. 5 6}$ & .42 \\
15. I have trouble carrying on two conversations at once & .11 &. $\mathbf{3 5}$ & .15 \\
17. After being distracted/easily shift my attention back & $\mathbf{4 6}$ & $\mathbf{. 4 0}$ & .44 \\
18. Distracting thoughts/shift attention away & .27 & .25 & .16 \\
19. It's easy for me to alternate between two different tasks & -.07 & $\mathbf{. 7 9}$ & .61 \\
\hline
\end{tabular}

Note. $h^{2}$ - communality of an item. Correlation of components $(r=.20)$. Components explained $40 \%$ of overall variability. Bold - items retained for CFA. 
we named this component "Shifting". Two items (4 and 17) loaded on both factors. Item $18 \mathrm{did}$ not load sufficiently on any of the components. Cumulatively, components accounted for $40 \%$ (Focusing $=26 \%$, Shifting $=14 \%$ ) of overall variance and were weakly positively related $(r=.20)$.

\section{Confirmatory Factor Analysis}

Please note that the sample for the CFA received only those items from the ACS which were retained after the PCA. In the first model, we let all items be saturated by one factor. This model did not yield an adequate fit $\chi^{2}=250.5$, $d f=104, p<.001, \chi^{2} / d f=2.4, C F I=.88, T L I=.86$, $R M S E A=.077, S R M R=.087$.

In the second model, we let items 1, 2, 3, 5, 6, $7,8,11,12$ be saturated by the first factor (Focusing), items 10,13,14,15, 19 by the second factor (Shifting) and items 4 and 17 were saturated by both factors. Factors were treated orthogonally. This structure showed even lesser appropriateness than the first model with values of $\chi^{2}=290.9, d f=102, p<.001, \chi^{2} / d f=2.85$, $C F I=.84, T L I=.82, R M S E A=.088$, and $S R M R=$ .092 .

In the third model, we directly followed suggestions made by PCA(Table 1). Therefore, the structure of the third model was the same as in the second one with exception of the allowed covariation between factors. This model resulted in considerably better fit, compared to the first model and significantly better fit compared to the second one $\left(\Delta \chi^{2}=30.01, \Delta p<.001\right.$, $\chi^{2} / d f=1.68, C F I=.94, T L I=.93, R M S E A=.053$, $S R M R=.072)$. However, values of fit indices were still unsatisfactory.

Throughout all models, modification indices (MI) suggested substantial model improvements by letting item 4 be saturated only by the Focusing factor and item 12 be saturated by the Shifting factor. Despite the suggestion of MI to let item 17 be saturated by both factors (leading to the best fit), to ensure better interpretability of the model, we let item 17 be saturated only by the Shifting factor. Furthermore, allowing covariation between error terms of items 10 and 19 revealed redundancy of item 10 (i.e., factor loading of item 10 substantially dropped from .50 to .30$)$ and hence, we decided to remove this item. Finally, we let error terms of items 7 and 8 covary, which did not result in considerable decrease in their factor loadings. For the convenience, we adjusted all previously tested models by these modifications and compared them again (Table 2).

Based on these results, we can conclude that acceptable fit is obtained under the assumption that items in the scale are saturated by two

Table 2 Fit indices of three compared models

\begin{tabular}{lcccccccccc}
\hline Model & $\chi^{2}$ & $d f$ & $p$ & $\chi^{2} / d f$ & $C F I$ & TLI & RMSEA & SRMR & $\Delta \chi^{2}$ & $\Delta p$ \\
\hline 1. One-factor & 156 & 89 & $<.001$ & 1.76 & .94 & .93 & .056 & .073 & - & - \\
2. Two-factor (orthogonal) & 381 & 89 & $<.001$ & 4.28 & .74 & .69 & .118 & .113 & - & - \\
3. Two-factor (correlated) & 102 & 88 & .137 & 1.18 & .99 & .98 & .026 & .059 & 93.2 & $<.001$ \\
\hline
\end{tabular}

Note. All models have been adjusted according to MIs. Reported value of $\Delta \chi^{2}$ in third row refers to the comparison between the second and the third model. Moving item 17 to Focusing factor did not result in considerable improvement of the two-factor correlated model $\left(\chi^{2}=99, d f=88, p=.198, \chi^{2} / d f=1.14, C F I=\right.$ $.99, T L I=.99, R M S E A=.023, S R M R=.058)$. Fit indices of the 3rd model with parallel saturation of item 17 were $\chi^{2}=85, d f=87, p=.524, \chi^{2} / d f=0.98, C F I=.99, T L I=.99, R M S E A=.000$, SRMR $=.054$. 
correlated factors. Nine items loaded on the Focusing factor and six items on the Shifting factor (Figure 1). All factor loadings were significant at $\mathrm{p}<.001$ and factors strongly and positively correlated (Table 3 ).

\section{Internal Consistency of ACS and its Subscales}

We conducted three separate analyses of internal consistency. First one analyzed internal consistency of the whole scale and the other two examined internal consistency of each subscale. Reliability estimate for the variance, which is only due to the general factor, yielded poor level with $\omega_{h}=.46$. However, considering the estimate of reliability for variance, which is due to the general factor as well as specific factors, we can conclude that the scale has good internal consistency $\omega_{t}=.85$. Coefficient $\beta=.60$ for the whole scale.

The results showed appropriate values of internal consistency indexes $\omega_{t}=.81, \alpha_{\text {ord }}=.81$ and $\beta=.61$ for the Focusing subscale. For the Shifting subscale, we observed the following values $\omega_{t}=.67, \alpha_{\text {ord }}=.66$ and $\beta=.53$ which might be considered as acceptable. Furthermore, average value of $\beta$ for both subscales is .585 , which is still less than that of $\beta$ coefficient for the whole scale, hence scores from both subscales may be combined into a single scale (Cooksey \& Soutar, 2006).

\section{Correlation of ACS with Measures of Trait Anxiety STAI-T and BIS Scales}

Data concerning the correlation between ACS and STAI-T were bivariate normal $(H Z=$ $.58, p=.65)$. We observed moderate, negative and significant correlation between these two measures, $r(330)=-.48, p<.001$, (Figure 2). ACS and BIS data exhibited bivariate non-normality $(H Z=1.66, p<.001)$. BIS was also negatively and significantly related to ACS scores, $\rho(130)=-.36, p<.001$. Correlation coefficients were not statistically different, $Z=1.40, p=$ .162. Next, we partialled out shared variance of Focusing and Shifting subscales and tested their relationship to measures of trait anxiety, respectively.

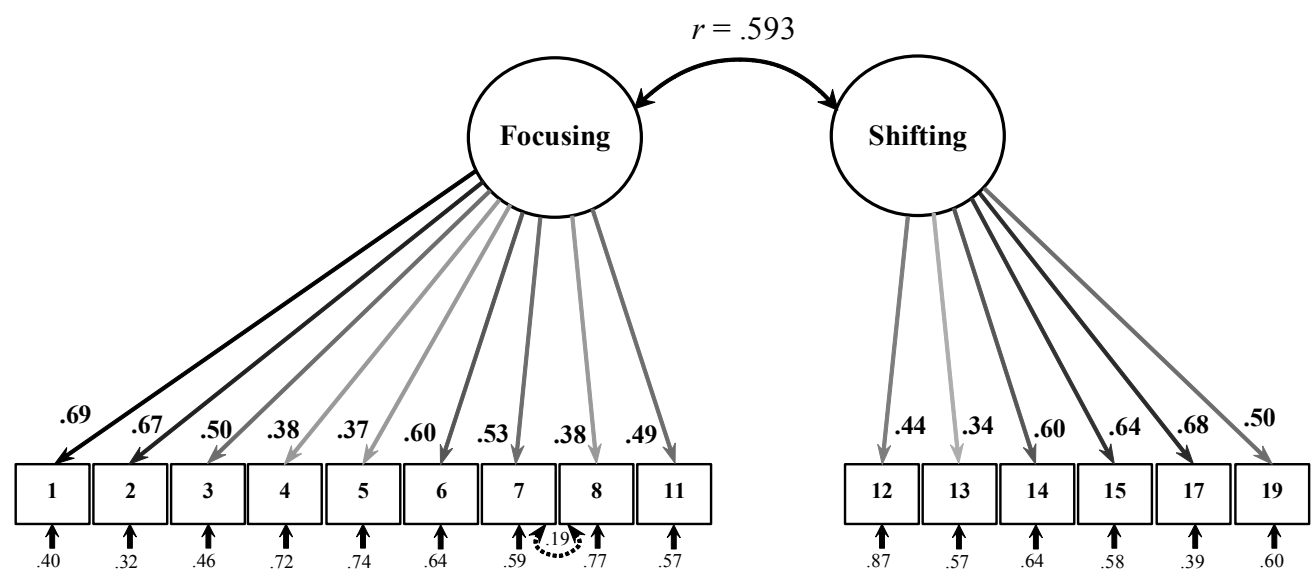

Figure 1 Path diagram of the third model after adjustments suggested by modification indices. Circles represent latent factors. Squares represent individual items of the scale. Numbers above the items denote standardized estimates and numbers below the items denote error terms. 
Table 3 Standardized estimates for two-factorial correlated model of ACS from CFA

\begin{tabular}{lcc}
\hline Item & $\begin{array}{c}\text { Focusing } \\
\text { (SE) }\end{array}$ & $\begin{array}{c}\text { Shifting } \\
\text { (SE) }\end{array}$ \\
\hline 1. Very hard to concentrate for me when there are noises around & $.69(.04)$ & $.67(.05)$ \\
2. When I need to concentrate on a difficult task/trouble focusing & $.50(.05)$ & \\
3. Working hard on something/get distracted by events around me & $.38(.06)$ & $.37(.06)$ \\
4. My concentration is good even if there is music in the room & $.60(.05)$ & $.53(.05)$ \\
5. When concentrating/focus attention/unaware of what's going on & $.38(.06)$ & $.49(.06)$ \\
6. When reading-studying/easily distracted if there are people talking & & $.44(.07)$ \\
7. Trying to focus my attention/difficult blocking distracting thoughts & & $.34(.07)$ \\
8. I have a hard time concentrating/when excited about something & $.60(.07)$ \\
11. It takes me a while to get really involved in a new task & & $.64(.05)$ \\
12. Difficult to coordinate my attention between writing and listening & & $.68(.06)$ \\
13. I can become interested in a new topic quickly when I need to & & $.50(.07)$ \\
14. Easy for me to read-write while I'm also talking on the phone & & \\
15. I have trouble carrying on two conversations at once & & \\
17. After being distracted/easily shift my attention back & & \\
19. It's easy for me to alternate between two different tasks &
\end{tabular}

Note. SE - robust standard errors of estimates. Factors were strongly positively related $(r=.593, p<$ $.001)$. All estimates were significant at $p<.001$.
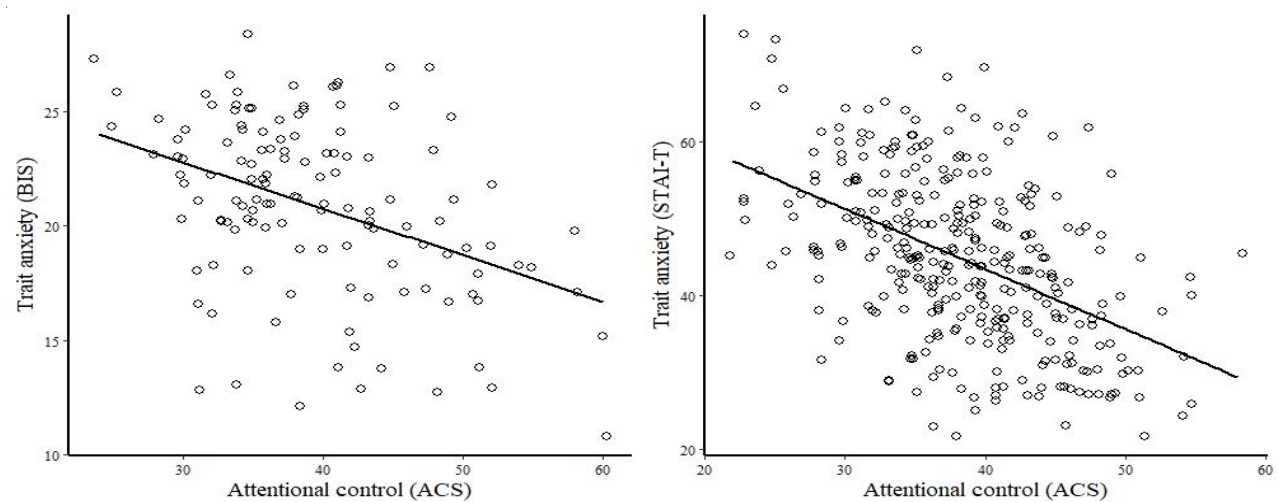

Figure 2 Left: correlation between ACS and BIS $(\rho(130)=-.36 p<.001)$; Right: correlation between ACS and STAI $(r(330)=-.48, p<.001)$. Small jitter (noise) was added to the plots to disperse overlaying data points. 
After controlling for Shifting, the Focusing subscale was significantly, moderately and negatively related to BIS, $\rho(130)=-.31, p<.001$. On the other hand, the Shifting subscale did not show significant relation to BIS after controlling for Focusing, $\rho(130)=-.09, p=.275$. STAI-T also yielded moderate, negative, and significant relationship with Focusing subscale, $r(330)=-.34, p<.001$. While Shifting subscale did not correlate with BIS, it did show weak negative association with STAI-T, $r(330)=-.18$, $p<.001$, however we should consider the size of the sample on which this correlation was estimated.

Additionally, we tested the samples for possible gender differences in the measured variables. No differences were observed either for the BIS, $U=1310.5, Z=-0.873, p=.383$, or for the ACS, $t(472)=1.181, p=.238$, and STAI-T, $U=10545.0, Z=-0.134, p=.893$.

\section{Discussion}

The current study tested psychometric properties of Slovak adaptation of the Attentional Control Scale by means of the PCA and CFA and its hypothesized relationship with trait anxiety. The PCA, using a parallel analysis, suggested two components, which indeed resembled two assumed factors of Focusing and Shifting. Importantly, some of the items that were excluded were also reported in other studies as being problematic (Judah, Grant, Mills, \& Lechner, 2014; Ólafsson et al., 2011). For example, Fajkowska and Derryberry (2010) examined the content and internal validity of ACS items by including them amongst other statements referring to formal characteristics from a temperament inventory measuring endurance. Four recruited judges were in good agreement, however they judged items 9 and 20 from the ACS incorrectly and replaced them with items measuring temperamental endurance. Item 9 has been also reported as problematic in the Icelan- dic version of the ACS (Ólafsson et al., 2011). Furthermore, reported studies differed fairly in their criteria concerning the retention of items in the final structure. In our study, we used only one criterion regarding the PCA, namely that factor loading must be equal or higher than .35 . However, in a study conducted by Judah, Grant, Mills, and Lechner (2014), the authors used rather strict constraints of factor loadings of at least .40 , with minimum factor loading difference between two components being .25. Although their procedure resulted in considerably smaller number of retained items (12), the main purpose of this approach was to distinguish both factors from each other as much as possible. Nevertheless, our results from the PCA supported two-factorial structure of the ACS.

Using the CFA on an independent sample, we found that from amongst one-factorial and two-factorial orthogonal solutions, the two-factorial model with correlated factors suggested by PCA fitted the data best. This is consistent with the hypothesized structure of the ACS, and although initial configuration of this model did not yield satisfactory fit across all fit indices, subsequent adjustments suggested by modification indices proved to be sufficient to meet their required values. Please note that these adjustments are of no theoretical value regarding the factor structure of the scale (i.e., slight change of saturation pattern and allowing covariation between error terms of items is still consistent with the hypothesized structure of the scale). Noteworthy are also the results that the one-factorial model exhibited better fit to data than the two-factorial orthogonal model and its fit indices could be considered as acceptable (after MI adjustments). Despite this, only the third model reached all required values of fit indices and, also, as the only one did not result in significant $\chi^{2}$ statistics. However, there were some differences in comparison to other studies. For example, we let item 12 be saturated by the Shifting factor instead of the Fo- 
cusing factor and even though this item was saturated by the Focusing factor in previous studies, we suggest that the content of this item (Appendix) resembles more the ability to shift rather than to focus attention. Also in comparison to the previous studies, we found item 10 to be redundant when allowed to correlate with item 19. Again, if we look at the content of these two items, we find that these statements are indeed very similar. Therefore, we removed item 10 from the final model ( $3^{\text {rd }}$ model $)$. Finally, probably most different from factorial solutions obtained in the previous studies are findings concerning saturations of items 11 and 17 . In the Icelandic version (Ólafsson et al., 2011), items 11 and 17 loaded on the Shifting factor. In a study by Judah, Grant, Mills, and Lechner (2014), item 11 did not reach sufficient loading, although it loaded more on the Focusing factor and item 17 was saturated only by the Shifting factor. In our study, the results of PCA and CFA (Tables 1 and 3) showed clearly greater contribution of the Focusing factor to item 11. We suspect that this is a result of specific wording in the Slovak language used in our translation. Instead of the word "involve", we used "focus". Similarly, the same might be true of item 17. This item showed approximately similar saturation by both factors in both PCA and CFA. Again, instead of "shift my attention back" we used "focus back on". Therefore, the subjects might have attributed this statement equally to the ability to reallocate attentional resources as well as to the ability to focus these resources.

In previous studies (Abasi, Mohammadkhani, Pourshahbaz, \& Dolatshahi, 2017; Judah, Grant, Mills, \& Lechner, 2014; Ólafsson et al., 2011) Cronbach's alpha was the only measure of internal consistency provided for the ACS. It is well documented that this coefficient provides only a lower bound and biased estimate of internal consistency (Graham, 2006; Zinbarg et al., 2005), since the tool does not measure a homogenous construct with the same precision.
We observed that this is indeed the case of ACS, which does not resemble only one homogeneous construct and furthermore, as PCA and CFA showed, contains items varying in factor loadings, and thus we proceeded with alternative measures of internal consistency. For the whole scale, we found internal consistency to be at a good level, as indicated by $\omega_{t}$. For individual subscales, estimates of internal consistency were fairly similar to those reported in the previous studies with Focusing subscale being the more stable construct. Shifting subscale, on the other hand, indicated a possible nonhomogeneity. Indeed, certain concerns about generalization of various shifting forms have been previously raised (Ravizza \& Carter, 2008). To tackle with the dissociation of different aspects of cognitive flexibility is beyond our subject, but we suspect that it is necessary to differentiate between the ability to alternate between two tasks with known and established rules (e.g., item 19 "It's easy for me to alternate between two different tasks") and the ability to adapt to a new set of rules (e.g., item 13 "I can get interested in a new topic very quickly when I need to").

We consistently observed a negative association between ACS and measures of trait anxiety. Although ACS correlated with STAI-T more strongly than with BIS, the correlation coefficients were not statistically different. However, Fajkowska and Derryberry (2010) reported similarly strong association between BIS and ACS as we evidenced between ACS and STAI-T. Importantly, one might suspect that these correlations could have been confounded by gender differences regarding the levels of trait anxiety or attentional control. However, direct comparisons of genders revealed no differences in all threemeasures. Moreover, we observed that only the Focusing subscale is significantly inversely related to trait anxiety. This is consistent with reports from a study by Ólafsson et al. (2011), which found lower levels of Focusing to be as- 
sociated with higher levels of trait anxiety and lower levels of Shifting to be associated with symptoms of depression. Although we found a weak correlation between the Shifting subscale and STAI-T, we did not measure levels of depressive symptoms and so we could not control for their shared variance, which is generally assumed between these two constructs.

Regarding the predictive and convergent validity of ACS, we may claim that there is certainly more research to be done. However, as authors of the scale (Derryberry \& Reed, 2002) demonstrated in their experiments, the scale could predict reduction of attentional bias toward threatening stimuli in highly anxious individuals. Recently, Judah, Grant, Mills, and Lechner (2014) found ACS together with its subscales to be related to performance-based measure of working memory capacity (Letternumber sequencing). More specifically, only the Shifting subscale showed positive correlation with this measure. Furthermore, utilizing the Mixed Antisaccade Task, Judah, Grant, Mills, and Lechner (2014) observed positive correlation between Focusing, antisaccade performance, and prosaccade latency. Shifting was found to be related to switch-trial performance on the Mixed Antisaccade Task. However, the scale's predictive and convergent validity should be tested against other executive control tasks, considering the multifaceted nature of executive functions as well (e.g., Miyake et al., 2000). For example, Derryberry (2002) discusses unpublished experiments, which showed high ACS scores to be related to better performance in stop-signal task or to better ability to inhibit dominant conceptual association in a priming task.

Taken together, the attentional control scale might prove useful due to its quick administration capabilities. For example, easy to use, the property of the scale might prove useful in research of stress or anxiety effects on cognitive control (i.e., controlling for individual differ- ences in the ability to reduce attentional bias). Finally, we should address the limitations of the current investigation. Perhaps the most noticeable one is the inequality of genders in both samples, however, we did not observe any possible mediating effect of this variable on the relationship between ACS and measures of trait anxiety. Moreover, as our sample consisted mainly of university students, the structure of the ACS should be tested also on a sample from a broader general population. Problematic is also the saturation of item 17. Given that letting this item be saturated either by the Focusing, or by the Shifting factor results in comparatively satisfying solutions, it makes the interpretation of this item arbitrary in terms of whether it is reflecting more the ability to focus or to shift attention. Perhaps a change in translation of this item should be considered in future investigations utilizing the Slovak version of ACS, leaning the meaning of this item only to the shifting ability.

\section{Summary}

The structure of the first Slovak version of the ACS supports the notion of this tool as being saturated by two positively related factors. The scale can be used to assess attentional control as a unitary construct or to assess individual components of Focusing and Shifting as well. Values of internal consistency for the whole scale and separate subscales promotes the usage of this tool mainly for research purposes. The next step should be to verify its validity either in correlational or experimental studies. Further investigation of its psychometric properties should be also conducted on a sample from the general population.

\section{References}

Abasi, I., Mohammadkhani, P., Pourshahbaz, A., \& Dolatshahi, B. (2017). The psychometric proper- 
ties of Attentional Control Scale and its relationship with symptoms of anxiety and depression: A study on Iranian population. Iranian Journal of Psychiatry, 12(2), 109-117

Bar-Haim, Y., Lamy, D., Pergamin, L., BakermansKranenburg, M. J., \& van IJzendoorn, M. H. (2007). Threat-related attentional bias in anxious and nonanxious individuals: A meta-analytic study. Psychological Bulletin, 133(1), 1-24. doi: 10.1037/00332909.133.1.1

Berggren, N., \& Derakshan, N. (2013). Attentional control deficits in trait anxiety. Why you see them and why you don't. Biological Psychology, 92(3), 440-446. doi: 10.1016/j.biopsycho.2012.03.007

Bishop, S. J. (2009). Trait anxiety and impoverished prefrontal control of attention. Nature Neuroscience, 12, 92-98. doi: 10.1038/nn.2242

Bowler, J. O., et al. (2012). A comparison of cognitive bias modification for interpretation and computerized cognitive behaviour therapy: Effects on anxiety, depression, attentional control, and interpretive bias. Journal of Consulting and Clinical Psychology, 80(6), 1021-1033. doi: 10.1037/ a0029932

Carver, C. S., \& White, T. L. (1994). Behavioural inhibition, behavioural activation, and affective responses to impending reward and punishment: The BIS/BAS scales. Journal of Personality and Social Psychology, 67(2), 319-333. doi: 10.1037/00223514.67.2.319

Cooksey, R. W., \& Soutar, G. N. (2006). Coefficient beta and hierarchical item clustering. Organizational Research Methods, 9(1), 78-98. doi: 10.1177/ 1094428105283939

Derryberry, D., \& Reed. M. (2002). Anxiety-related attentional biases and their regulation by attentional control. Journal of Abnormal Psychology, 111(2), 225-236

Derryberry, D., \& Rothbart, M. K. (1988). Affect, arousal, and attention as components of temperament. Journal of Personality and Social Psychology, 55, 958-966

Eden, A. S., et al. (2015). Emotion regulation and trait anxiety are predicted by the microstructure of fibers between amygdala and prefrontal cortex. The Jour nal of Neuroscience, 35(15), 6020-6027. doi: 10.1523/JNEUROSCI.3659-14.2015

Eysenck, M. W., \& Calvo, M. G. (1992). Anxiety and performance: The processing efficiency theory. Cognition and Emotion, 6, 409-434. doi: 10.1080/ 02699939208409696

Eysenck, M. W., Derakshan, N., Santos, R., \& Calvo, M. G. (2007). Anxiety and cognitive performance: attentional control theory. Emotion, 7(2), 336-53. doi: $10.1037 / 1528-3542.7 .2 .336$
Flora, D. B., \& Curran, P. J. (2004). An empirical evaluation of alternative methods of estimation for confirmatory factor analysis with ordinal data. Psychological Methods, 9(4), 466-491. doi: 10.1037/ 1082-989X.9.4.466

Fowles, D. C. (1987). Application of a behavioural theory of motivation to the concepts of anxiety and impulsivity. Journal of Research in Personality, 21, 417-435. doi: 10.1016/0092-6566(87)90030-

Fox, E., Russo, R., \& Georgiou, E. A. (2005). Anxiety modulates the degree of attentive resources required to process emotional faces. Cognitive, Affective, \& Behavioral Neuroscience, 5, 396-404

Gaderman, A. M., Guhn, M., \& Zumbo, B. D. (2012). Estimating ordinal reliability for Likert-type and ordinal item response data: A conceptual, empirical, and practical guide. Practical Assessment, Research \& Evaluation, 17(3), 1-12

Graham, M. J. (2006). Congeneric and (essentially) tau-equivalent estimates of score reliability: What they are and how to use them. Educational and Psychological Measurement, 66(6), 930-944. doi: 10.1177/0013164406288165

Hadwin, J. A., \& Richards, H. J. (2016). Working memory training and CBT reduces anxiety symptoms and attentional biases to threat: A preliminary study. Frontiers in Psychology, 7(47), 1-12. doi: $10.3389 /$ fpsyg. 2016.00047

Henze, N., \& Zirkler, B. (1990). A Class of invariant consistent tests for multivariate normality. Journal of Multivariate Analysis, 62, 1-23. doi: 10.1080/ 03610929008830400

Hermans, E. J., Henckens, M. J. A. G., Joëls, M., \& Fernández, G. (2014). Dynamic adaptation of largescale brain networks in response to acute stressors. Trends in Neurosciences, 37(6) 304-314. doi: $10.1016 / \mathrm{j}$.tins. 2014.03 .006

Horn, J. L. (1965). A rationale and test for the number of factors in factor analysis. Psychometrika, 30, 179185. doi: 10.1007/BF02289447

Judah, M. R., Grant, D. M., Mills, A. C., \& Lechner, W. V. (2014). Factor structure and validation of the attentional control scale. Cognition and Emotion, 28(3), 433-451. doi: 10.1080/02699931.2013. 835254

Kim, M. J., \& Whalen P. J. (2009). The structural integrity of an amygdala-prefrontal pathway predicts trait anxiety. Journal of Neuroscience, 29(37), 11614-11618. doi: 10.1523/JNEUROSCI.233509.2009

Koster, E. H. W., Crombez, G., Verschuere, B., Van Damme, S., \& Wiersema, J. R. (2006). Components of attentional bias in high trait anxiety: Facilitated engagement, impaired disengagement, and atten- 
tional avoidance. Behaviour Research and Therapy, 44, 1757-1771. doi: 10.1016/j.brat.2005.12.011

Miyake, A., et al. (2000). The unity and diversity of executive functions and their contributions to complex 'frontal lobe' tasks: A latent variable analysis. Cognitive Psychology, 41, 49-100. doi: 10.1006/ cogp.1999.0734

Öhman, A. (2005). The role of amygdala in human fear: Automatic detection of threat. Psychoneuroendocrinology, 30, 953-958. doi: 10.1016/j. psyneuen.2005.03.019

Ólafsson, R. P., et al. (2011). Self-reported attentional control with attentional control scale: Factor structure and relationship with symptoms of anxiety and depression. Journal of Anxiety Disorders, 25, 777782. doi: 10.1016/j.janxdis.2011.03.013

Posner, M. I., \& Petersen, S. E. (1990). The attention system of human brain. Annual Review of Neuroscience, 13, 25-42. doi: 10.1146/annurev.ne.13. 030190.000325

Ravizza, S. M., \& Carter, C. S. (2008). Shifting set about task switching: Behavioral and neural evidence for distinct forms of cognitive flexibility. Neuropsychologia, 46, 2924-2935. doi: $10.1016 / \mathrm{j}$. neuropsychologia.2008.06.006

Revelle, W. (1979). Hierarchical cluster analysis and the internal structure of tests. Multivariate Behavioural Research, 14, 57-74. doi: 10.1207/ s15327906mbr1401 4

Revelle, W. (2017). psych: Procedures for Personality and Psychological Research. Northwestern University, Evanston, Illinois, USA, https://CRAN.Rproject.org $/$ package $=$ psych Version $=1.7 .8$

Rosseel, Y. (2012). lavaan: An R package for Structural Equation Modeling. Journal of Statistical Software, 48(2), 1-36. doi: 10.18637/jss.v048.i02
Satorra, A. (2000). Scaled and adjusted restricted tests in multi-sample analysis of moment structures. In R. D. H. Heijmans, D. S. G. Pollock, \& A. Satorra (Eds.), Innovations in multivariate statistical analysis. A Festschrift for Heinz Neudecker (pp. 233-247). London: Kluwer Academic Publishers.

Spielberger, C., Gorusch, R., \& Lushene, R. (1970). STAI manual. Palo Alto. Consulting Psychologist Press.

Taylor, C. T., Cross, K., \& Amir, N. (2016). Attentional control moderates the relationship between social anxiety symptoms and attentional disengagement from threatening information. Journal of Behavior Therapy and Experimental Psychiatry, 50, 68-76. doi: 10.1016/j.jbtep.2015.05.008

Telzer, H. E., et al. (2008). Relationship between trait anxiety, prefrontal cortex, and attention bias to angry faces in children and adolescents. Biological Psychology, 79(2), 216-222. doi: 10.1016/j. biopsycho.2008.05.004

Ullman, B. J. (2006). Structural equation modelling: Reviewing the basics and moving forward. Journal of Personality Assessment, 87(1), 35-50. doi: 10.1207/s15327752jpa8701_03

Verstraeten, K., Vasey, M. W., Claes, L., \& Bijttebier, P. (2010). The assessment of effortful control in childhood: Questionnaires and the test of everyday attention for children compared. Personality and Individual Differences, 48, 59-65. doi: 10.1016/ j.paid.2009.08.016

Zinbarg, R. E., Revelle, W., Yovel, I., \& Li, W. (2005). Cronbach's $\alpha$, Revelle's $\beta$, and McDonald's $\omega_{\mathrm{H}}$ : Their relations with each other and two alternative conceptualizations of reliability. Psychometrika, 70(1), 123-133. doi: 10.1007/s11336003-0974-7 


\section{APPENDIX}

Attentional Control Scale in Slovak Language

Item

1. Je pre mňa vel'mi t’ažké sústredit' sa na náročnú úlohu, ked' je v mojom okolí hluk. (R)

2. Ked' sa potrebujem sústredit' a riešit' úlohu, je pre mňa t’ažké zamerat' na ňu moju pozornost'. (R)

3. Ked’ na niečom t’ažko pracujem, veci okolo mňa ma neustále vyrušujú. (R)

4. Dokážem sa dobre koncentrovat', aj ked'v mojom okolí hrá hudba.

5. Ked' sa sústredím, dokážem tak zamerat' svoju pozornost', že prestanem vnímat', čo sa deje naokolo.

6. Ked' čítam alebo sa učím a v miestnosti sú d’alší l'udia, ktorí sa rozprávajú, l'ahko ma to vyruší. (R)

7. Je pre mňa t'ažké blokovat' rušivé myšlienky, ked' sa snažím na niečo sústredit'. (R)

8. Je pre mňa t’ažké koncentrovat' sa, ak som nadšený/á alebo vzrušený/á. (R)

9. Ked' sa sústredím, ignorujem pocity hladu alebo smädu.

10. Dokážem rýchlo preskočit' z jednej úlohy na druhú.

11. Chvíl'u mi trvá, kým sa skutočne začnem sústredit' na novú úlohu. (R)

12. Ked' si počas prednášky píšem poznámky, je pre mňa náročné koordinovat' moju pozornost' medzi počúvaním a písaním. (R)

13. Ked' je to potrebné, dokáže ma nová úloha zaujat' vel'mi rýchlo.

14. Je pre mňa jednoduché niečo čítat' alebo písat', aj ked' popri tom telefonujem.

15. Mám problém viest’ dve konverzácie naraz. (R)

16. Je pre mňa náročné príst' rýchlo s novým nápadom. $(\mathrm{R})$

17. Ak ma niečo vyruší, dokážem sa opät' l’ahko sústredit’ na to, čo som robil/a predtým.

18. Ked' mi na um zíde rušivá myšlienka, je pre mňa l’ahké odpútat' od nej moju pozornost'.

19. Pri práci je pre mňa jednoduché preskakovat' medzi dvoma odlišnými úlohami.

20. Pri riešení úlohy je pre mňa t’ažké prestat' o nej rozmýšl'at' jedným spôsobom a pozriet' sa na ňu z iného uhla pohl'adu. (R)

Note. Only items with designated number in bold were retained after PCA and CFA. (R) item with reversed scoring. Items are scored on a 4-point Likert scale $(1$ - almost never; 2 - sometimes; 3 -often; 4 - always) (Derryberry \& Reed, 2002). 